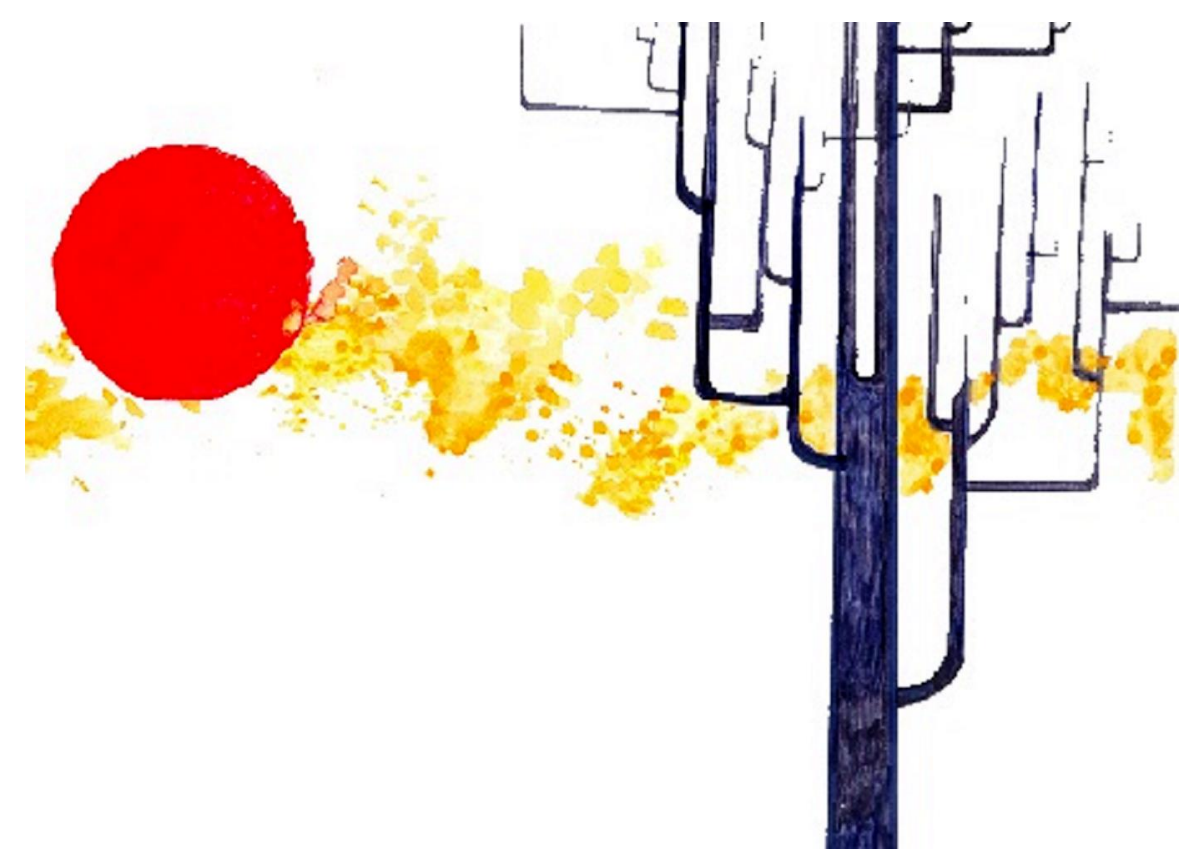

João Paulo Tiago

\title{
Por onde caminhar?
}

\section{Douglas Veloso}

Graduado em Artes Visuais pela Universidade Federal de Minas Gerais. Restaurador, pintor e artista gráfico, com atuação no Arquivo Público Mineiro, em Belo Horizonte. Escreve crônicas, ensaios e letras-poesia.

\section{Fragmentos}

Quebra, lacunas, pedaços de um chão, ruínas de algo inexistente. Nem todos os olhos conseguem enxergar um detalhe nesse chão, uma rachadura que seja. Muito menos olhar por onde andam. Descobrir ruínas em coisas novas se torna um exercício. É como trocar as mãos quando se quer pintar. É como descobrir um ponto entre um amontoado de cores. Cores de verdade ou cores falsas. Cinzas, pretos ou amarelos. Se quiser descobrir detalhes, basta desviar de pessoas sem tempo, que também caminham sobre pretos e cinzas. Papéis são jogados pra trás, mesmo tendo cores e fotos. Escondem seus olhos azuis ou castanhos em relógios e celulares. E correm com medo do tempo. E correm com seus sapatos pretos pra pegar ônibus azuis e vermelhos ou carros prateados, que furam sinais vermelhos. Como se o tempo fosse se extinguir, como se fosse arruinar 
algo que ainda não existe. Como se o tempo fosse apenas o que nos falta. Ruínas de imagens passadas, imagens de televisão. E no final o que nos resta? Nada talvez. Basta apenas apertar parafusos, reclamar do governo e fazer feijão branco ou preto. Correr por escadas, por estradas pretas faltando pedaços. E acordar cedo pra ver o céu cinza, impresso na espessura de uma linha. Mas os mais atentos conseguem ver o azul, o laranja. Mas as cores chamam a atenção demais e parar pra se perceber um detalhe custa caro. Detalhes são pequenas provas encontradas por cães em meio aos escombros. Fragmentos de processos, fragmentos de cor e coisas que estavam escondidas entre concretos e bueiros resolvem aparecer. Surgem pra dizer que, apesar de extintas e falsas, elas podem combinar com as cores dos nossos olhos, da nossa pele e do nosso tempo.

\section{Realidade não construída}

Por onde começar a não ser duvidando da realidade? Eu duvido porque ela se mistura com cores e com tudo que pode ser nada. Estranho, parece que a realidade tomou coragem. Queimou um pouco e pegou uma cor. Pegou não, tomou. A realidade toma uma cor que, misturada com outra qualquer, se torna prova-chave do lugar. É que o que nos resta é comer restos de cor de um passado de luz. Passado de luz ligado por controles remotos, em alta definição. A realidade toma uma cor que, misturada com um significado qualquer, se torna elemento de diferenciação. Alguém pode dizer que essas cores todas estão fora do lugar. Podem até dizer que as mãos também estão. Esse alguém tem a cabeça branca demais, parece papel. Talvez alguns fragmentos de cor devem ter permanecido nessa cabeça. Nem que seja um cinza, desses da década de 60 que aparecem na televisão. Assim como nossos olhos se perdem em meio ao cinza, o cinza se perde em meio a suportes, dentro do campo da arte visual. As cabeças assim se escondem de vergonha quando não percebem isso.

\section{Corpo dilacerado}

Escondendo do tempo, dilacero meu corpo. Minhas mãos torcem pra sair, pra abrir mão de certos tons. Minha cabeça ainda preta está muito longe daquela cabeça branca sem ao menos um cinza. Ao menos não se esconde do papel. Estradas faltando pedaços para se percorrer com vermelho. Cores de mais ou de menos, brancos de mais ou de menos. Depende da cor de suas calças sem pernas. Pernas cortadas como papel. Que as cabeças estejam atentas ao novo movimento do corpo, que dança louco como um ruivo descalço. Que as cabeças esqueçam o toque dos celulares e lembrem do gesto do aceno de longe. Braços soltos em meio ao mar de linhas e tons azuis. Parecem pipas em meio à neblina que vem do nada. 
Txt: Leituras Transdisciplinares de Telas e Textos, Belo Horizonte, v.4, n.7, p.116-118, 2008

E alguém aqui resolveu fazer algo, sem reclamar do governo. Se o dinheiro é azul, deve ser bonito, ele me disse. Cortando os pulsos, estragou o papel de vermelho. Cansou de esperar o ônibus azul na pista central. Cortou a cabeça de vergonha quando ninguém percebeu isso.

Junho de 2007. 